\title{
IDEOLOGI ZIONISME DALAM TIMBANGAN TEOLOGI ISLAM: KAJIAN ATAS RASISME DALAM PEMIKIRAN ZIONISME
}

\author{
M. Kholid Muslih \\ Universitas Darussalam Gontor Ponorogo \\ Email:kholid.muslih@gmail.com \\ Amal Fathullah Zarkasyi \\ Universitas Darussalam Gontor Ponorogo \\ Email:Amal.fathullah.amal@gmail.com
}

\author{
Abdul Rohman \\ Universitas Darussalam Gontor Ponorogo, Indonesia \\ E-mail:abdulrohman@mhs.unida.gontor.ac.id \\ Rahmat Adi Nur Rifa Da'i \\ Universitas Darussalam Gontor Ponorogo, Indonesia \\ E-mail:masday1387@gmail.com
}

\begin{abstract}
Zionism is one of the great agenda of the Jewish nation to rule the world. The movement can be considered far from human values, all of which originate from their ideology contained in the Talmud and Protocols of Zion. This article aims to reveal the basic ideas of Zionism which became their principle in the movement to conquer the world. Through a search of the literature regarding the theme of the discussion and the descriptive-critical analysis method, it is hoped that it can explain the racism side of the Zionist ideology which is clearly contrary to Islamic Islamic theology and human values. This study shows several important points, including: first, Zionism is a movement of the Jewish people to reclaim Baitul Maqdis; second, the Modern Zionism Movement was initiated by Theodor Herzl through the establishment of the Modern State of Palestine; third, the Zionist movement is based on their ideology taken from the Talmud and the Protocols of Zion. The core ideology in these two sources is to assert that the Jews are the best nation in the world, nations other than them are considered not descendants of Adam and even considered animals, God has given the Jews the rights to rule over all nations other than them, and so on; Fourth, the ideology of Zionism if viewed from the perspective of
\end{abstract}


Islamic theology there are many mistakes because basically Allah views all human beings as equal and the only difference is their piety, there are some confusions in the Zionist conception of God, and some of their ideologies have confusion between argument one and argument. other. Therefore, the author concludes that the ideology of Zionism is contrary to the point of view of Islamic theology, besides that it is also not in accordance with the principles of humanity.

Keywords: racism; zionism ideology; protocols of zion; talmud; islam

\begin{abstract}
Abstrak
Zionisme merupakan salah satu agenda besar bangsa Yahudi untuk menguasai dunia. Gerakannya bisa dianggap jauh dari nilai kemanusiaan, di mana semua itu bersumber dari ideologi mereka yang ada dalam Kitab Talmud dan Protocols of Zion. Artikel ini bertujuan untuk mengungkap dasar-dasar pemikiran Zionisme yang menjadi prinsip mereka dalam gerakan menaklukkan dunia. Melalui penelusuran literatur-literatur berkenaan dengan tema pembahasan dan metode deskriptif-analisis kritis diharapkan dapat menjelaskan tentang sisi rasisme ideologi Zionisme yang itu jelas bertentangan dengan teologi Islam dan nilai kemanusiaan. Penelitian ini menunjukkan beberapa poin penting, di antaranya yaitu: pertama, Zionisme merupakan gerakan bangsa Yahudi untuk merebut kembali Baitul Maqdis; kedua, Gerakan Zionisme modern diprakarsai oleh Theodor Herzl melalui pembentukan Negara Modern Palestina; ketiga, Gerakan Zionisme tersebut didasari oleh ideologi mereka yang diambil dari Kitab Talmud dan Protocols of Zion. Inti ideologi dalam kedua sumber ini adalah menegaskan bahwa bangsa Yahudi merupakan bangsa terbaik di dunia, bangsa selain mereka dianggap bukan keturunan Adam bahkan dianggap hewan, Tuhan telah menganugrahi bangsa Yahudi hakhak untuk menguasai seluruh bangsa selain mereka, dan lain sebagainya; keempat, ideologi Zionisme tersebut jika ditinjau dari perspektif teologi Islam terdapat banyak kesalahan karena pada dasarnya Allah memandang semua umat manusia itu sama dan yang membedakannya hanyalah ketakwaannya, terdapat beberapa kerancuan dalam konsepsi Zionis tentang Tuhan, dan beberapa ideologi mereka memiliki kerancuan antara argumen satu dengan argument lain. Oleh karena itu, penulis menyimpulkan bahwa ideologi Zionisme bertentangan dengan sudut pandang teologi Islam, selain itu juga banyak tidak sesuai dengan prinsip kemanusiaan.
\end{abstract}

Kata Kunci: rasisme; ideologi zionisme; procols of zion; talmud; teologi islam 


\section{Pendahuluan}

Salah satu pergolakan yang kontroversial dan menimbulkan banyak konflik di beberapa penjuru dunia adalah gerakan Zionisme. Gerakan ini merupakan suatu aktivitas keagamaan dan politik dari bangsa Yahudi yang menginginkan kembalinya Yudaisme ke tanah yang dijanjikan yakni Tanah Suci "Palestina" (al-Ardh al-Muqaddasab). ${ }^{1}$ Padahal bagi umat Islam, kota ini memiliki sejarah penting, yaitu tempat berdakwahnya para rasul dan kiblat pertama bagi umat Islam $^{2}$ serta tempat Isra' Nabi Muhammad untuk kemudian melanjutkan Mi'rajnya ke Sidratul Muntaha. Tempat ini juga merupakan salah satu di antara tiga masjid yang Allah rekomendasikan untuk dikunjungi. ${ }^{3}$ Di sisi Kristen, Palestina dianggap sebagai tempat kelahiran Nabi Isa a.s. Dan sejarah juga mencatat bahwa Palestina, sekitar 3000 tahun SM menjadi tempat hijrah kabilah Kan'an. ${ }^{4}$ Sejarah inilah yang kiranya menjadikan Palestina sebagai perebutan antara pihak Yahudi dengan Islam.

Zionis mengambil sebagian dari tanah Palestina dan berusaha untuk mencapainya dengan berbagai cara, seperti konflik, perang, dan senjata, dengan mengklaim haknya di Baitul Maqdis. Tidak hanya itu, mereka ingin mengambil alih dunia untuk menjadi penguasanya dan menjadikan orang-orang yang bersama mereka menjadi tidak berdaya untuk melawan kekuatan mereka. Gerakan Zionis ini sudah termasuk gerakan rasisme bahkan terorisme karena telah dilakukannya pembantaian yang dilakukan kepada

1 'Abd al-Wahhāb Muḥammad Al-Maysirī, Al-Idiyūlü̈izyyah Al-Ṣuhyūniyyah (Beirut: 'Ālam al-Ma'rifah, 1982), 7.

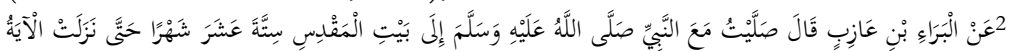

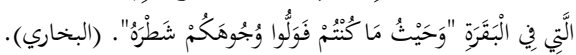

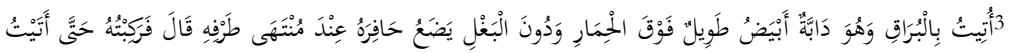

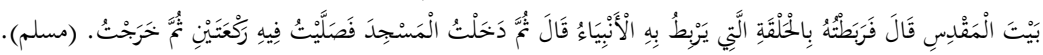

${ }^{4}$ Muhammad Mehna Al-'Aliyy, "Sira'unā Ma'a Al-Yahūdiyyah Baina AlȘulḥ Al-Mustahịil Wa Muwājahah Al-Ḥatmiyyah,” Vol. 1 (Riyad: Dār “Āmiyyah li al-Naṣr wa al-Tauzī', 1993), 37-38.

TAJDID vol. 20, No. 2, Juli - Desember 2021 | 271 
M. Kholid Muslih, Amal Fathullah Zarkasyi, Abdul Rahman, Rahmat Adi Nur Rifa Da’i

rakyat Palestina. ${ }^{5}$ Problem yang dimunculkan oleh Zionis sudah merupakan problem umat Islam di dunia bukan hanya di Palestina juga termasuk problem kemanusiaan.

Pada awal abad ke-20 ini, lebih tepatnya sejak kembalinya bangsa Yahudi ke Palestina yang diprakarsai oleh Zionisme, seringkali terjadi konflik antara pihak Yahudi dan negara Arab. Konflik ini diawali pada saat Dawlah Utsmaniyyah mengalami kekalahan dalam Perang Dunia Pertama (1914-1918) ${ }^{6}$ dan mengalami puncaknya pada tanggal 14 Mei 1948 saat bangsa Yahudi memproklamirkan Negara Israel Modern. ${ }^{7}$ Situasi konflik ini terus terjadi hingga masa sekarang, dengan ditandai adanya perlawanan balik dari Palestina yang dipimpin oleh HAMAS kepada Israel. ${ }^{8}$ Pada tahun 1980 muncul kebangkitan umat muslim Palestina dan bersatu untuk membela diri dan membebaskan diri dari jajahan Israel. ${ }^{9}$ Upaya pembelaan dan pembebasan Palestina juga dilakukan melalui pengajuan tuntutan atas Israel ke Mahkamah Kejahatan International (ICC) yang dilakukan untuk pertama kalinya pada tahun $2015 .{ }^{10}$ Usaha untuk mengembalikan kebebasan Palestina atas Israel ini dapat dikatakan sebagai bentuk jihad karena demi menjaga keberlangsungan hidup manusia, harkat, martabat, dan hak hidup dalam kesamaan emosi dan

5 Tasnim Abdul Rahman et al., "Konflik Islam Dan Israel Di Palestina: Tentangan, Isu, Dan Penyelesaiannya Dalam Karya AL-Faruqi," UMRAN: International Journal of Islamic and Civilizational Studies 2, no. 2 (2015): 8.

${ }^{6}$ Ermy Azziaty Rozali and Azmul Fahimi Kamaruzaman, "First World War, Balfour Declaration and Their Impacts on Palestine: Perang Dunia Pertama, Deklarasi Balfour Dan Kesannya Terhadap Palestina," International Journal of West Asian Studies 3, no. 2 (2011): 20, https://doi.org/DOI: 10.5895/ijwas.2011.08. 78-81.

7 Aguk Irawan MN, Rahasia Dendam Israel (Jakarta: Kinza Books, 2009),

8 Mahlil Idatul Khumairoh and Abdul Fadhil, "Gerakan Intifadhah Dan Kemunculan Hamas (1987-1993)," PERIODE: Jurnal Sejarah Dan Pendidikan Sejarah 1, no. 1 (2019): 3.

9 A. Misri Muchsin, "PALESTINA DAN ISRAEL: Sejarah, Konflik Dan Masa Depan," Jurnal Miqot 39, no. 2 (2015): 401.

10 Moh. Rosyid, "Dinamika Perjuangan Muslim Di Palestina," Fikrah: Jurnal Ilmu Aqidah Dan Studi Keagamaan 3, no. 2 (2015): 225. 
keberagamaan, ${ }^{11}$ atau dengan kata lain merupakan usaha amar ma'ruf nabi munkar. ${ }^{12}$ Upaya-upaya untuk membebaskan Palestina dari jajahan Israel terus dilakukan hingga saat ini baik dari pihak Palestina, maupun negara-negara Islam di dunia (termasuk Indonesia), bahkan negara non-muslim lain yang ikut prihatin terhadap penderitaan rakyat Palestina.

Gerakan frontal yang dilakukan oleh Zionis dalam upaya menguasai Palestina (Baitul Maqdis) yang didasari sikap rasisme berasal dari pemikiran-pemikiran mereka. Pemikiran-pemikiran Zionis semuanya diambil dari Kitab Talmud yang merupakan hasil dari distorsi dan penyelewengan makna dari Kitab Suci Taurat. ${ }^{13}$ Selain itu, Zionisme juga mengambil isi Protocols of Zion sebagai landasan pemikiran. ${ }^{14}$ Rasisme yang ditunjukkan dalam Talmud dan Protocols of Zion inilah yang membuat tekad mereka untuk menguasai Palestina (khususnya) dan dunia (umumnya) semakin kuat.

Penulis menemukan beberapa artikel tentang Zionisme maupun konflik Palestina-Israel. Di antaranya artikel yang ditulis oleh Roma Ulinnuha di Jurnal Religi yang berjudul "Yahudi dalam Sudut Pandang Filosofis Studi Agama" mengkaji tentang agama Yahudi yang dilihat dari sudut pandang filosofis studi agama guna menciptakan perdamaian. ${ }^{15}$ Selanjutnya artikel Nur Fadilah Yusuf dan Retno Winarni dalam jurnal Historia yang berjudul "Strategi Politik dalam Merebut Palestina dari Kerajaan Utsmani Tahun 1896-1948” yang membahas terkait strategi politik Zionis dalam

${ }^{11}$ Muhammad Julkarnain, "Resolusi Jihad Muslim Nusantara Abad XVIII: Interpretasi Jihad 'Abd Al-Samad Al-Falimbani," Tajdid 15, no. 1 (2016): 51.

12 Badarussyamsi, M. Ridwan, and Nur Aiman, "Amar Ma'ruf Nahi Munkar: Sebuah Kajian Ontologis,” Tajdid 19, no. 2 (2020): 274.

${ }^{13}$ Rajā 'Abd al-Hamīd 'Arābī, Safar Al-Tārìkh Al-Yabūdì (Suriah: Al-Awāil li al-Nashr wa al-Tawzì', 2006), 331-55.

14 'Abbās Maḥmūd Al-'Ifār, Al-Khaṭr Al-Yahūdì: Burtūkūlāt Hukamā Ṣubyūn (Beirut: Dār al-Kitāb al-'Arabī, 1961).

${ }^{15}$ Roma Ulinnuha, "Yahudi Dalam Sudut Pandang Filosofis Studi Agama: Kontra Zionisme Dan Kontribusi Kelompok Naturei Karta Pada Klausul Perdamaian," Jurnal Religi 9, no. 1 (2015): 1-3.

TAJDID vol. 20, No. 2, Juli - Desember 2021 | 273 
M. Kholid Muslih, Amal Fathullah Zarkasyi, Abdul Rahman, Rahmat Adi Nur Rifa Da’i

merebut Palestina dari kekuasaan Kerajaan Turki Utsmani. ${ }^{16}$ Artikel Andi Satrianingsih dan Zaenal Abidin di Jurnal Adabiyah dengan judul "Sejarah Zionisme dan Berdirinya Negara Israel" pembahasannya terkait dengan sejarah lahirnya Zionisme dan kaitannya dengan berdirinya Negara Israel. ${ }^{17}$ Sedangkan, artikel Ulya Fuhaidah di Jurnal Review Politik berjudul "Analisis Peluang Kedaulatan Negara Palestina" fokus membahas terkait konflik yang terjadi di Palestina dan pengaruhnya terhadap masa depan Palestina. ${ }^{18}$ Dan terakhir artikel dari Mubarak dengan judul "Yahudi dan Islam dalam Lintas Sejarah (Studi Perspektif Islam terhadap Yahudi)" mengkaji Yahudi dari sisi sejarahnya dan relasinya dengan Islam. ${ }^{19}$

Artikel-artikel di atas semuanya fokus kajiannya hanya dari sudut pandang sejarah dan politik, namun ada juga sebagian yang mengkaji pemikiran Zionisme, akan tetapi tidak melakukan kritik terhadapnya. Oleh karena itu, artikel ini akan mengkaji lebih lanjut terkait sisi rasisme pemikiran Zionisme dan bagaimana sudut pandang Islam atas hal tersebut. Artikel ini berjenis kajian kepustakaan (library research), dan data-data diambil dari buku maupun artikel terkait Zionisme. Metode penelitian kualitatif dengan pendekatan deskriptif-analitis penulis terapkan untuk menjabarkan temuan data, kemudian data terkait pemikiran Zionisme yang sudah dianalisa akan penulis kaji secara kritis dari perspektif Islam.

${ }^{16}$ Nur Fadilah Yusuf and Retno Winarni, "Strategi Zionis Politik Dalam Merebut Palestina Dari Kerajaan Utsmani Tahun 1896-1948," Historia 3, no. 1 (2020): 303.

17 Andi Satrianingsih and Zaenal Abidin, "Sejarah Zionisme Dan Berdirinya Negara Israel,” Jurnal Adabiyah 16, no. 3 (2016): 172.

18 Ulya Fuhaidah, "Analisis Peluang Kedaulatan Negara Palestina," Jurnal Review Politik 2, no. 1 (2012): 114.

19 Mubarak, "Yahudi Dan Islam Dalam Lintas Sejarah: Studi Perspektif Islam Terhadap Yahudi," Jurnal Al-Adyan 6, no. 2 (2019): 241. 


\section{Pengertian Term Zionisme}

Sebelum kita memperkenalkan Zionisme, kita harus mengetahui maknanya, secara etimologi dan terminologi. Ada beberapa versi mengenai asal usul nama Zionisme. Beberapa sarjana melihat bahwa kata Zionisme dikaitkan dengan salah satu dari empat gunung dimana kota "Aurushlimm" (artinya kota perdamaian) dibangun, yang merupakan nama lama Yerusalem yang terletak di Selatan. ${ }^{20}$ Dan beberapa dari mereka beranggapan bahwa kata ini berasal dari bahasa Arab "al-Shawn wa al-Tahshin" (perlindungan dan benteng). Dari hasil penelitian juga terlihat bahwa kata ini merujuk pada benteng al-Quds. ${ }^{21}$

Tetapi pendapat di atas pada dasarnya sama, dan semua itu menunjukkan bahwa Zionisme adalah sebuah bukit yang digunakan sebagai tempat penjagaan atau perlindungan, dan Nabi Daud a.s., pernah menjadikannya istana setelah dia pindah dari Hebron pada abad ke-11 SM. Di sinilah pertama kali direncanakannya pembangunan sebuah kuil (baikal) oleh Nabi Daud dan diselesaikan oleh Nabi Sulaiman a.s., tahun 953 SM. Kuil itu berdiri kokoh selama kurang kebih 374 tahun, hingga ketika Babilonia menghancurkannya pada masa kepimpinan Nebokadesnar dalam perang selama sembilan hari pada tahun 586 SM. Kemudian haikal itu dibangun kembali oleh Herodes Agung pada tahun 20 SM. Setelah orang-orang Yahudi memerintah lagi, haikal tersebut direnovasi. Akan tetapi dihancurkan lagi oleh Romawi setelah penaklukan pada tahun $70 \mathrm{M}^{22}$

Sejak saat itu, mereka menganggap suci bukit Sion (di mana lokasinya di Masjid al-Aqsa), dan mereka percaya bahwa Tuhan

20 'Alī Muḥammad Grishāh Al-Zubaiq and Muhạmmad Sharīf, Al-Asālīb Al-Ghažn Al-Fikrī Li Al-'Ālam Al-Islāmì (Kairo: Dār al-I’tișām, 1979), 151.

21 Muḥammad Al-Ḥasan, Al-Madhähib Wa Al-Afkär Al-Mu'așirah Fì AlTaṣawwur Al-Islāmì (Ṭanțā: Dār al-Bashīr li al-Thaqāfah wa al-'Ulūm al-Islāmī, 1999), 351.

22 Abū Bakr, Madhāhib Fikriyyah Fì Al-Mī̄ạn (Kairo: Dār al-'Aqiīdah, 2002), 215.

TAJDID vol. 20, No. 2, Juli - Desember 2021 | 275 
M. Kholid Muslih, Amal Fathullah Zarkasyi, Abdul Rahman, Rahmat Adi Nur Rifa Da’i

bersemayam di dalamnya, seperti yang disebutkan dalam Yesaya 2:3, ${ }^{23}$ dan Mazmur 137:1, ${ }^{24}$ berdasarkan asal usul kata Zionisme. Sedangkan, Ahmad al-Salabi mendefinisikan Zionisme sebagai tanah air Bani Israel di Palestina, yaitu di sekitar Bukit Zion. Zionis adalah orang Yahudi yang ingin tinggal di Palestina, termasuk para pendukung mereka yang secara moral juga ingin menetap di Palestina. ${ }^{25}$

Adapaun makna Zionisme secara terminologi juga terdapat pendapat yang berbeda-beda. Di antaranya adalah pendapat Muhammad al-Hasan, bahwa Zionisme adalah gerakan politik Yahudi rasis yang namanya diambil dari Gunung Zion, selatan Yerusalem, dan bertujuan untuk mengembalikan kejayaan Israel dengan mendirikan negara Yahudi di Palestina. ${ }^{26}$ Sementara itu, Alwi 'Abd al-Halim Mahmoud mengatakan bahwa Zionisme merupakan suatu gerakan Yahudi yang mengusahakan dengan segala cara untuk memulihkan kerajaan Bani Israel, dan membangun haikal Sulaiman di atas reruntuhan Masjid al-Aqsha. Kemudian ingin menguasai dunia dan kekuasaannya ada di Yerusalem tepatnya di tangan Raja orang Yahudi, yakni seorang Mesias yang diharapkan kedatangannya dengan syarat dia dari keturunan Daud. ${ }^{27}$

Dari pemaparan arti kata Zionisme di atas, kita bisa memahami bahwa Zionisme diambil dari nama Gunung Sion yang

23 "Banyak suku akan pergi dan berkata: Mari, kita telah naik ke gunung Allah, ke rumah Allah wahai Ya'qub. Agar, Dia dapat mengajari kita petunjukpetunjuk-Nya dan agar kita dapat berjalan di atasnya, karena Sion akan membawa ajaran-ajaran dan firman-firman Allah dari Yerusalem." Sion."

24 "Di tepi Sungai Babel, kami duduk dan menangis ketika kami mengingat

25 Aḥmad Shulbī, Muquaranah Al-Adyān Al-Awwal: Al-Yahüdiyyah, Juz 5 (Kairo: Maktabah al-Nadwah al-Maysaroh, 1978), 126.

26 Al-Hasan, Al-Madhäbib Wa Al-Afkēr Al-Mu'ạsirah Fì Al-Tașanwur AlIslämī, 351 .

27 'Alwi 'Abd al-Ḥalīm Maḥmūd, Al-Ghaẓn Al-Fikeri Wa Al-Tayyārāt AlMa'ādiyyah Li Al-Islām (Riyadl: Idārah al-Thaqāfah wa al-Nashr bi al-Jāmi’ah, n.d.), 486. 
terletak di selatan Yerusalem, dan disucikan oleh orang-orang Yahudi. Zionisme adalah gerakan atau organisasi yang melakukan kegiatan keagamaan, politik, etnis, kolonial, dan global (seluruh dunia). Mereka bertujuan mendominasi dunia dengan mendirikan Negara Israel sebagai pijakan. Dan dapat disimpulkan juga bahwa Zionisme memiliki dua tujuan, yaitu agama dan politik.

\section{Sejarah Gerakan Zionisme}

Nama Zionisme digunakan di masa lalu untuk sekte Yahudi yang menunggu kehadiran al-Masih untuk dibawa ke kerajaan Allah, seperti yang tertulis dalam kisah Nabi Ibrahim dan Nabi Musa. Kemudian ini menjadi dasar kemunculan gerakan Zionisme dalam bentuk gerakan politik yang ditujukan untuk mengembalikan mereka ke tanah yang dijanjikan. ${ }^{28}$ Di samping itu, kemunculan gerakan Zionis karena tuntutan hak-hak sosial, ekonomi, politik, budaya dan agama, setelah mereka terpaksa hidup dalam diaspora negara-negara. ${ }^{29}$ Kemudian mereka ingin agar orang-orang Yahudi yang tinggal di berbagai negara mengakhiri penderitaan mereka dengan kembali ke tanah leluhur mereka, Palestina. Sehingga, dalam gerakannya mereka berurusan dengan beberapa konflik seperti pembantaian, penganiayaan, penindasan, dan pengusiran di Rusia barat, yang menyebabkan perubahan dari pemikiran ke gerakan, sehingga Zionisme berkembang ke seluruh belahan dunia. ${ }^{30}$

Zionisme Global memiliki akar sejarah, intelektual, dan politik, dan kita dapat merangkumnya sebagai berikut. ${ }^{31}$ Kata Zion pertama kali muncul dalam Perjanjian Lama ketika diungkapkan kepada Raja Daud, yang mendirikan kerajaannya (1000-960 SM). Kemudian muncul gerakan penduduk Makabe yang kembali dari

${ }^{28}$ Shulbī, Muquaranah Al-Adyān Al-Awwal: Al-Yahüdiyyah, 99.

29 Leonard C. Epafras, "Memahami Ingatan Kuktural Yahudi Dalam Konflik Israel-Palestina,” Jurnal Kawistara 3, no. 2 (2013): 156.

${ }^{30}$ Shulbī, Muquaranah Al-Adyān Al-Awwal: Al-Yahüdiyyah, 102.

31 "Alwī Ibn "Abd al-Qādir Al-Saqāf, "Mawsū'ah Al-Milal Wa Al-Adyān," Juz 1, n.d., 18.

TAJDID vol. 20, No. 2, Juli - Desember 2021 | 277 
M. Kholid Muslih, Amal Fathullah Zarkasyi, Abdul Rahman, Rahmat Adi Nur Rifa Da’i

pembuangan Babilonia (586-538 SM), dan tujuan pertamanya adalah kembali ke Zion untuk membangun haikal Sulaiman. Dan gerakan Barkuchia (118-138 M), orang Yahudi ini membangkitkan semangat di hati kaum Yahudi, dan mendesak mereka untuk berkumpul di Palestina untuk mendirikan negara Yahudi di sana. Selanjutnya gerakan Moses Kreta, yang mirip dengan gerakan Barkuchia. ${ }^{32}$

Terdapat periode stagnasi dalam aktivitas Yahudi karena penganiayaan dan penyebaran orang-orang Yahudi. Namun, gerakan David Rubin dan muridnya Solomon Moloch (1501-1532 M) berhasil mendesak kaum Yahudi agar kembali kepada tujuan mendirikan Negara Israel di Palestina. Dan gerakan munculnya gerakan Manaseh bin Israel (1604-1657 M), yang pertama kali mengarahkan dan memfokuskan rencana Zionisme untuk mencapai tujuan mereka dengan menjadikan Inggris sebagai alatnya. $^{33}$

Awal mula munculnya istilah Zionisme di tangan penulis Jerman Nathan Birnbaum pada tahun 1893 Masehi. Pada tahun $1882 \mathrm{M}$, sebuah gerakan yang dikenal sebagai (Cinta Sion) muncul di Rusia untuk pertama kalinya, ${ }^{34}$ dan para pendukungnya berkumpul dalam sebuah lingkaran yang disebut (Pencinta Sion), dan kelompok-kelompok ini diakui pada tahun $1890 \mathrm{M}$ di bawah nama "Jami'ah Musa'adah al-Shina' wa al-Muzari in al-Yabud fi Suria wa Filisthin" (Asosiasi untuk Membantu Produsen dan Petani Yahudi di Suriah dan Palestina) yang dipimpin oleh Leon Pinsker.

32 Māni’ Ḥammād al-Jawhānī, "Al-Mawsū'ah Al-Muyassarah F̄̄ Al-Adyān Wa Al-Madhāhib Wa Al-Ahzāb Al-Mu'āṣirah,” Juz 1 (Riyad: Dār al-Nadwah al'Ālamiyyah li al-Ṭibā'ah wa al-Nashr wa al-Tawzī,' n.d.), 521-23.

33 Dāud 'Abd al-'Afw Sinokrot, Al-Yahūd Fì Al-Waṭn Al-'Arabì (Oman: Dār al-Furqān, 1983), 9.

34 Al-Ḥasan, Al-Madhāhì Wa Al-Afkēr Al-Mu'āșirah Fì Al-Tașawwur AlIslämi, 354 .

278 | TAJDID vol. 20, No. 2, Juli - Desember 2021 
Kelompok ini bertujuan untuk mendorong imigrasi ke Palestina dan menghidupkan kembali bahasa Ibrani. ${ }^{35}$

Adapun Zionisme modern adalah sebuah gerakan yang dikaitkan dengan Theodor Herzl, seorang jurnalis Yahudi Hungaria. Tujuan utamanya yang jelas adalah memimpin orangorang Yahudi untuk menguasai dunia, dimulai dengan pendirian negara mereka di Palestina. Sultan Abdul Hamid II bernegosiasi dalam hal ini dalam upaya, tetapi gagal. Pada saat itu, Yudaisme internasional bekerja untuk menggulingkan Sultan dan menghapuskan Khilafah Islam. ${ }^{36}$ Usaha kudeta yang dilakukan Herzl dibantu oleh Gerakan Turki Muda dan berhasil merubah sistem pemerintahan dari monarki absolut ke monarki konstitusi. Peristiwa ini dalam sejarah dikenal dengan nama Revolusi Turki Muda. ${ }^{37}$

Herzl kemudian mengadakan Konferensi Zionis Internasional pertama pada tahun $1897 \mathrm{M},{ }^{38}$ dengan mengambil keuntungan dari perwira pengadilan Yahudi Prancis yang bernama Dreyfus, yang menuduh mereka berkhianat 1894 M, untuk mentransfer rahasia militer dari Prancis ke Jerman, tetapi ketidakbersalahannya kemudian terbukti. Dalam klaimnya, melalui insiden ini Herzl menerbitkan bukunya yang terkenal berjudul "The Jewish State" setelah memenangkan dukungan untuknya yang mendorong dia untuk mengadakan Konferensi Zionis pertama di Basel, Swiss. Dia mengomentarinya dengan mengatakan, "Jika dia meminta saya untuk meringkas karya konferensi, maka saya katakan, lebih tepatnya, saya memanggil semua orang bahwa saya telah mendirikan negara Yahudi." Dia berhasil mengumpulkan

35 Nihād Al-Ghādirī, Al-Tārìkh Al-Sirrī Li Al-'Alāqāt Al-Shuyū'Tyyah AlȘubyūniyyah (Beirut: Manshūrāt Dār al-Kitāb al-'Arabī, 1969), 42.

${ }^{36}$ Nadā Al-Shaqifī, Al-Holocaust: Haqìqatihà Wa Al-Ishtighäl Al-Șubyūnì Lahā (Beirut, 2011), 175.

37 Ahmad Rofi' Usmani, Ensiklopedia Tokoh Muslim (Bandung: PT. Mizan Pustaka, 2015), 123.

38 Al-Shaqifì, Al-Holocaust: Haqüqatibā Wa Al-Ishtighäl Al-Ṣubyūnī Lahā, 179.

TAJDID vol. 20, No. 2, Juli - Desember 2021 | 279 
M. Kholid Muslih, Amal Fathullah Zarkasyi, Abdul Rahman, Rahmat Adi Nur Rifa Da’i

orang-orang Yahudi di seluruh dunia, sebagaimana ia berhasil mengumpulkan kelicikan orang-orang Yahudi yang mengeluarkan keputusan paling berbahaya dalam sejarah dunia, yakni protokol Para Tetua Sion (Protocols of Zion) yang berasal dari ajaran bukubuku orang Yahudi yang sudah dirubah dan mereka sucikan. Sejak saat itu orang-orang Yahudi telah memperketat organisasi mereka. Mereka telah bergerak dengan presisi, licik, dan tidak terlihat untuk mencapai tujuan destruktif mereka, yang hasilnya terlihat jelas di zaman sekarang. ${ }^{39}$

\section{Ideologi Zionisme: Kajian atas Kitab Talmud dan Protocols of Zion}

Zionis memperoleh kaedah-kaedah pemikirannya dari Talmud (kitab suci yang telah dirusak dan dirubah oleh orangorang Yahudi) dan Protocols of Zion (rumusan-rumusan pemikiran, tujuan, dan gerakan Zionis). Tercatat pada tahun 1901, pendeta gereja Ortodox dari Rusia Bernama Prof. Sergey Nilus berhasil menerjemahkan Protocols of Zion. Itu adalah dokumen rahasia yang ditemukan oleh seorang wanita Fremassonry yang berkhianat. ${ }^{40}$ Poin penting dari isi Protocols of Zion ada sembilan, di antaranya adalah: Pertama, hendaklah dipahami bahwa golongan manusia yang mempunyai tabiat jahat, lebih banyak jumlahnya dari bagian manusia yang mempunyai tabiat yang mulia. Kalau begitu, maka cara yang terbaik untuk menguasai dunia ialah dengan merampas kekuasaan dan ancaman, bukan dengan perundingan akademik. Kedua, apabila kekuatan masyarakat sudah tidak seimbang lagi, maka kekuatan kita akan menjadi lebih teguh daripada kekuatankekuatan yang lain, sebab kekuatan itu akan tetap tersembunyi, sehingga detik-detik terakhir, di mana tidak akan ada kekuatan apapun yang dapat menyaingi atau menghancurkannya. Ketiga,

39 Abū Jābir and Ibrāhīm, Qadliyyah Al-Quds Wa Mustaqbalubā Fì Al-Qarn Al-Hāài Wa Al-Ishrinn (Oman: Markaz Dirāsāt al-Shirq al-Awsaṭ, 2002), 185.

40 Muhammad Baharun, Isu Zionisme Internasional (Yokyakarta: Pustaka Pelajar, 1979), 4.

280 | TAJDID vol. 20, No. 2, Juli - Desember 2021 
media surat kabar adalah satu-satunya kekuatan besar yang melalui jalan ini, kita dapat memimpin dunia. Media surat kabar dapat menyajikan keinginan-keinginan yang segar buat rakyat jelata, menyebarkan pengaduan-pengaduan orang yang kecewa, dan akan menimbulkan perasaan bosan pada diri orang-orang pengacau. Kini media surat kabar telah berada di tangan kita, dan berkat jasa media surat kabar, kita telah memperoleh pengaruh, menimbung emas tanpa sepasang mata pun dari masyarakat luas dapat melihatnya. ${ }^{41}$

Keempat, sesungguhnya manusia akan lebih muda ditundukkan dengan bencana kemiskinan daripada ditundukkan oleh undangundang perhambaan yang terjadi di dunia. Dari perhambaan, ada juga seseorang yang dapat memerdekakan dirinya dengan suatu cara, tetapi tidak akan memungkinkan sesuatu pun yang dapat memerdekakan mereka dari bahaya kemiskinan. Kelima, kita telah berhasil menaburkan benih-benih perpecahan antara perseorangan, sebagaimana kita telah berhasil menaburkannya antara umat-umat di dunia, dan kita telah menyebarkan fanatisme sekitar agama dan kiblat selama 20 abad. Oleh sebab itulah, tidak akan ada kemungkinan lagi bagi orangorang perseorangan dapat bersatu padu dan tidak pula antar umat akan bertemu. Keenam, agar kita berhasil merusak industri kaumkaum asing, kita akan menambah gaji kaum-kaum buruh, akan tetapi pada saat yang bersamaan kita akan menaikkan harga barang-barang pokok untuk menutup kembali kenaikan gaji-gaji tadi. Dengan demikian, kita akan dapat merusak industri itu dan mencelakakan kaum buruh. ${ }^{42}$

Ketujuh, apabila kita telah mempunyai kedudukan yang kuat, dan kita pun telah menjadi tuan-tuan di atas bumi ini, maka kita tidak akan membenarkan agama-agama selain agama kita berdiri tegak, dan dengan demikian kita telah menghapuskan

\footnotetext{
${ }^{41}$ Ahmad Salaby, Agama Yahudi (Jakarta: Bumi Aksara, 1996), 259.

42 Salaby, 302.
} 
M. Kholid Muslih, Amal Fathullah Zarkasyi, Abdul Rahman, Rahmat Adi Nur Rifa Da’i

semua kepercayaan agama-agama lain, dan ketika itu juga para ahli falsafah kita akan dapat mengungkapkan semua keburukankeburukan agama asing. Kedelapan, kita akan mencela kehormatan para ahli agama bangsa asing supaya kita berhasil memburukkan terhadap putusan-putusannya, dan dalam masa yang tidak lama lagi hanya dalam beberapa tahun saja agama Kristen akan mengalami kemerosotan ketingkat yang paling rendah, kemudian akan berturut-turut akan menyusul agama-agama lainnya, dan raja Israel akan mejadi "pope" kepada alam. ${ }^{43}$ Semua isi Protocols of Zion di atas menunjukkan ambisi Zionis untuk menguasai dunia dan sudah terpatri dalam pikiran dan hati mereka.

Termasuk kitab terpenting yang dijadikan pedoman oleh orang Yahudi atau Zionis adalah Talmud. Mereka mengklaim bahwa beberapa risalah dalam Talmud dikutip dari kata-kata Nabi Musa yang keluar dari lisannya sendiri. Padahal sejak dahulu meskipun sampai turunnya Nabi Isa sebelum hari kiamat nanti dia tidak akan mengajarkan Talmud. Faktanya, Nabi Isa mengkritik kitab Mishnah (Talmud pertama) dan orang yang mengajarkannya, karena isi kitab itu semuanya sesat, dan bahkan bertentangan dengan Taurat. Para Rabbi Yahudi menambahkan keterangan palsu dalam Mishnah suatu ajaran yang disebut kitab Gemarah. Ini adalah kitab tafsir yang dikarang oleh Rabbi Yahudi. Selanjutnya, Mishnah tersebut lebih dikenal sebagai Talmud. Talmud dibagi menjadi dua bagian yaitu Talmud al-Quds (Yerusalem) dan Talmud Babilon (Babilonia). Orang-orang Yahudi dan Zionis berpendapat bahwa Talmud Babilonia adalah yang paling otoritatif. Dia mengklaim bahwa Talmud lebih baik dan lebih benar daripada Taurat, seperti yang dikatakan Rabbi Yahiel bin Yoseph, "Tanpa Talmud kita tidak memahami ayat-ayat Taurat. Tuban telah menganugerabkan keistimewaan ini kepada orang-orang bijak... Orangorang bijak tersebut mengarang tafsir-tafsir mereka (yang berupa Talmud)... Mereka yang tidak mempelajari Talmud tidak dapat memahami Taurat."

\footnotetext{
${ }^{43}$ Salaby, 304.
}

282 | TAJDID vol. 20, No. 2, Juli - Desember 2021 
Selain itu, tertulis di dalam Talmud Erubin 2b, "Wabai anakku, kamu harus mendabulukan fatwa Abli Kitab (Talmud) daripada ayat-ayat Taurat." ${ }^{\text {,4 }}$

Di antara ajaran di dalam Talmud yang paling fundamental dan kontroversial adalah sebagai berikut: Pertama, orang-orang Yahudi bertujuan untuk mendirikan pemerintahan mereka sendiri dan menguasai dunia seperti yang dijanjikan oleh Tuhan mereka, Yahweh dalam Kitab Perjanjian Lama. Tanah yang dijanjikan tersebut terbentang dari Sungai Nil sampai Sungai Efrat. ${ }^{45}$ Kedua, keyakinan akan datangnya al-Masih, seorang utusan Tuhan yang datang dari bukit Zion dan dari trah Nabi Daud untuk menyelamatkan mereka serta membalaskan dendam kepada semua bangsa. ${ }^{46}$ Ketiga. Mereka percaya telah dijanjikan tanah Palestina seperti dalam Taurat, di mana mereka merujuk pada Perjanjian Lama, "Dan pada hari itu Tuban membuat perjanjian dengan Abrabam, dengan mengatakan: Untuk. keturunanmu Aku memberikan tanah ini dari Sungai Mesir ke sungai Efrat". Dokumen atau teks ini hanya ditemui dalam Perjanjian Lama, yang dikembangkan oleh para rabbi. Sekalipun kita menerima argumentasi keabsahan datanya, Tuhan tentu tidak akan memberi mereka tanah tersebut dan mengusir penduduk aslinya yang menetap di sana, karena hal ini bertentangan dengan keadilan Allah. Allah membuat orang-orang Yahudi bersumpah sebelum mengusir mereka dari Baitul Maqdis dengan tiga sumpah yaitu: pertama, mereka tidak akan kembali ke tanah Palestina sebelum munculnya Kristus dari dalam kelompok mereka meskipun mencoba memaksakannya. Kedua, mereka tidak akan bisa memberontak kepada seluruh dunia. Ketiga, orang-orang

${ }^{44}$ R.C. Musaph-Andriesse, From Torah to Kabbalah: A Basic Introduction to the Writings of Judaism (Britania Raya: Oxford University Press, 1982), 40; Z.A. Maulani, Zionisme: Gerakan Menaklukekan Dunia (Jakarta: Daseta, 2002), 89.

${ }^{45}$ Māni' Ḥammād al-Jawhānī, "Al-Mawsū'ah Al-Muyassarah F̄̄ Al-Adyān Wa Al-Madhāhib Wa Al-Ahzāb Al-Mu’āșirah,” 52.

46 'Ala Bakr, Mazabib Fikriyah Fi Al Mizan (Kairo: Dar al-'Aqidah, 2002), 221; Ali Muhammad Jareshah Al-Zeibik and Muhammad Sharif, Asalib AlGhazw Al-Fikriy Li Al-'Alam Al-Islamiy (Kairo: Dar al-I'tisham, 1975), 154-56. 
M. Kholid Muslih, Amal Fathullah Zarkasyi, Abdul Rahman, Rahmat Adi Nur Rifa Da’i

Yahudi berusaha memperjuangkan pemandekan diaspora dengan cara kepulangan mereka sebelum kedatangan Kristus. ${ }^{47}$

Keempat, orang-orang Yahudi meyakini bahwa mereka adalah ras terbaik yang harus menang dan selainnya harus melayani mereka. ${ }^{48}$ Mereka juga menganggap bahwa semua orang nonYahudi itu kafir, dan jika orang kafir itu menindas orang Yahudi, maka dia harus dibunuh, seperti ditulis dalam Talmud (Sanhedrin 58b). Akan tetapi, jika orang kafir dihakimi secara zalim (tidak adil), mereka tidak wajib meminta maaf dan memberikan keadilan kepada mereka. Mereka boleh mengambil harta orang kafir karena bagi Yahudi Zionis orang kafir itu tidak memiliki jaminan hukum. Seperti dalam Talmud (Sanhedrin 57a \& Baba Kamma 73b) mengatakan bahwa semua anak laki-laki kafir itu berasal dari ras binatang dan anak perempuan mereka hukumnya najis sejak mereka lahir. Klaim ini muncul karena bagi mereka orang-orang kafir bukanlah anak cucu Nabi Adam a.s., seperti yang tertulis dalam Talmud (Yebamoht 98a \& Abodah Zarah 36). ${ }^{49}$

Kelima, di antara kepercayaan mereka adalah bahwa Nabi Adam menyetubuhi binatang di surga. Akan tetapi lucunya, semua rabbi Yahudi dan kaum mereka bersih dari dosa, dan dia akan masuk surga nanti di akhirat, seperti disebutkan dalam Talmud (Yebamoht Hagigah 63a \& 27a). Keenam, termasuk paling rusaknya kepercayaan mereka adalah seperti yang tertulis dalam Talmud (Baba Mezia 59b) bahwa, "Pendeta Zionis beradu argumen dengan Tuhan (Yahweh). Dalam perdebatan itu pendeta berhasil mengalahkan Yahweh sampai dia mengakui kemenangan si pendeta dan dia pergi dari medan debat itu. ${ }^{.50}$

47 Muḥammad Bakhrabeh, Al-Ṣubyuniyyah Bi Ijāz Aṣl Nash'ab AlMukhatțațät Al-Subyūniyyah Al-'Álamiyyah Dhät Al-Naz'Ah Al-'Unșuriyyah, 2001, $1-2$.

48 Māni’ Ḥammād al-Jawhānī, "Al-Mawsū'ah Al-Muyassarah Fī Al-Adyān Wa Al-Madhāhib Wa Al-Ahzāb Al-Mu’āṣirah,” 52.

${ }^{49}$ Maulani, Zionisme: Gerakan Menaklukekan Dunia, 90-91.

${ }^{50}$ Maulani, 90-93. 
Ketujuh, Zionis akan mengusahakan berbagai cara agar tercipta masyarakat dekaden tanpa adanya nilai kemanusiaan dan moral, membenci agama dan politik, dan menghapus dari pikiran mereka gagasan tentang keberadaan Tuhan dan menggantinya dengan hukum matematika materialisme. Satu-satunya harapan Zionis adalah untuk mendapatkan perlindungan diri dari faham materialisme yang mereka tanamkan. Tujuannya adalah agar saat itupun musuh-musuhnya tidak akan berdaya untuk melawan. Mereka tunduk dan takluk di bawah kekuatan Zionis. ${ }^{51}$

\section{Kritik Islam terhadap Rasisme Pemikiran Zionisme}

Pemikiran-pemikiran Zionisme yang terdapat dalam Protocols of Zion maupun Talmud jika kita kaji lebih dalam dan kritis lagi, menunjukkan hal-hal yang berbau rasisme dan tentunya jelas berbeda dan menyeleweng dari kaedah-kaedah Islam. Secara etimologi, term 'Rasisme' berasal dari kata racism (bahasa Inggris) dan diambil dari kata race, yang mempunyai tiga arti yaitu: pertama, suatu pengelompokan populasi didasari pada kriteria genetik. Kedua, kelas sosial berdasarkan dari genotip-genotip. Ketiga, populasi yang jika dilihat dari sisi genetis tidak sama dengan populasi lainnya (ras). ${ }^{52}$ Sedangkan, secara terminologi, rasisme didefinisikan sebagai suatu tindakan dari suatu kelompok tertentu yang berasumsi bahwasanya kelompok mereka lebih superior dan lebih berkelas daripada kelompok lain. ${ }^{53}$ Sikap superior ini biasanya muncul karena ada sebuah gagasan bahwasanya terdapat kaitan kasual antara karakteristik jasmaniah yang diturunkan dan juga karakteristik tertentu yang ada dalam kepribadian, budaya, dan

51 Māni’ Ḥammād al-Jawhānī, “Al-Mawsū'ah Al-Muyassarah F̄̄ Al-Adyān Wa Al-Madhāhib Wa Al-Ahzāb Al-Mu’āṣirah,” 521.

52 Soerjono Soekamto, Kamus Sosiologi Jakarta: Raja Grafindo Persada, 1993), 360.

${ }^{53}$ Daniel Surya Andi Pratama, "Representasi Rasisme Dalam Film Cadillac Records," Jurnal E-Komunikasi 4, no. 1 (2016): 4. 
M. Kholid Muslih, Amal Fathullah Zarkasyi, Abdul Rahman, Rahmat Adi Nur Rifa Da’i

intelektual. ${ }^{54}$ Seringkali rasisme berkaitan dengan kelompok nonbiologis dan non-rasial, seperti sekte keagamaa, kebangsaan, kebahasaan, etnik, dan kultural maupun hanya sebuah prasangka yang seringkali dilihat dari stereotip dan kecemburuan sosial. ${ }^{55}$

Ditinjau dari pengertian rasisme di atas, maka terdapat empat hal yang terkait dengan sikap rasisme, sebagai berikut: pertama, perbedaan ras. Perbedaan ras seringkali diidentikkan dengan perbedaan warna kulit. Perbedaan tersebut faktanya sering memicu lahirnya tindakan yang mengunggulkan rasnya secara personal. Sehingga, timbul superioritas ras karena itu ras yang dirasa superior akan menindas ras yang dianggap lebih rendah. ${ }^{56}$ Kedua, perbedaan etnik. Etnik diartikan sebagai kelompok sosial yang terbentuk dari ras, adat-istiadat, nilai, budaya, bahasa, di mana mengindikasikan adanya kelompok minoritas dan mayoritas pada suatu masyarakat. ${ }^{57}$ Ketiga, perbedaan suku. Suku dipahami sebagai kelompok sosial dalam sistem atau kebudayaan yang memiliki arti dan juga kedudukan tertentu yang didapat karena adanya adat, agama, garis keturunan, bahasa, dan lainnya. ${ }^{58}$ Keempat, perbedaan bangsa. Bangsa atau suku bangsa memiliki pengertian sebagai kelompok sosial, dimana kelompok tersebut mempunyai sistem interaksi, sistem norma yang mengatur interaksi itu, adanya kontunuitas dan identitas yang menyatukan semua anggota serta memiliki sistem kepemimpinan tersendiri. ${ }^{59}$ Keempat faktor tersebut ketika ditunggangi teori superior atau teori

${ }^{54}$ N. Daldjoeni, Ras-Ras Umat Manusia: Biogeografis, Kulturbistoric, Sosiopolitis (Bandung: Citra Aditya Bakti, 1991), 81.

55 Ramon Grosfoguel, "What Is Racism?," Journal of World-System Research 22, no. 1 (2016): 7.

56 Hesti Armiwulan Sochamawardiah, Deskriminasi Rasial Dalam Hukum

Ham: Studi Tentang Deskriminasi Terbadap Etnis Tionghia (Yogyakarta: Genta Publising, 2013), 60.

57 Alo Liliwesi, Prasangka Dan Konflik: Komunikasi Lintas Budaya Multikultur (Yogyakarta: LKiS, 2005), 8.

58 Boenjamin Setiawan et al., Ensiklopedia Nasional Indonesia (Jakarta: PT. Cipta Adi Pustaka, 1990), 325.

${ }^{59}$ Zulzani Hidayah, Ensiklopedia Suku Bangsa Di Indinoseia (Jakarta: LP3ES, 1996), xxii. 
kelebihan akan menjadikan penganut paham rasisme melakukan tindakan-tindakan diskriminasi dan penyelewengan hak-hak kelompok selain kelompok mereka sendiri.

Dari sini, kita dapat mengetahui sisi rasis pemikiran Zionis yaitu pada sisi perbedaan bangsa, ras, dan etnik. Ini dapat dilihat seperti ketika Zionis mengatakan apabila Yudaisme adalah agama yang dibawa oleh Nabi Musa a.s. Pandangan ini adalah keliru, karena Nabi Musa tidak pernah membawa Yudaisme melainkan Islam. Akan tetapi yang dimaksud Islam di sini adalah Islam dalam pengertian umumnya, yakni berserah diri (istislam) kepada Allah Tuhan Yang Maha Esa. Sebagaimana Allah berfirman dalam alQur'an bahwasanya agama semua nabi dan rasul dari Nabi Nuh a.s., hingga Nabi Muhammad saw., adalah Islam. Allah Swt.,

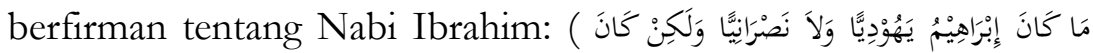

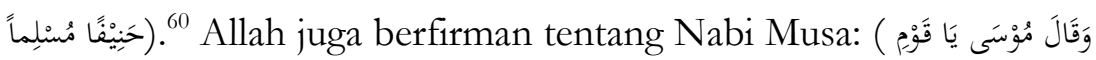

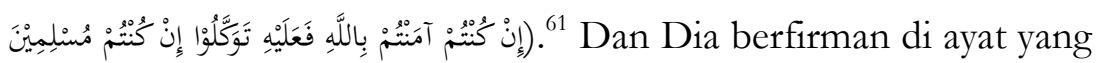

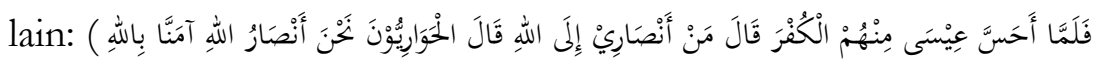
的. ${ }^{62}$ Adapun makna Islam dalam pengertian khusus adalah syariat yang ada di dalam al-Qur'an yang diturunkan kepada Nabi Muhammad. Islam dalam definisi khusus ini mengajarkan tauhid dan pokok-pokok agama yang dibawa oleh Nabi Muhammad. ${ }^{63}$ Dari apa yang telah dijelaskan sebelumnya, menjadi jelas bahwa Yudaisme adalah agama palsu yang menyimpang dari agama yang benar yang dibawa oleh Nabi Musa.

Kerusakan ideologi Zionisme lainnya adalah kesalahan keyakinan mereka dalam memahami surga dan neraka. Mereka mengklaim bahwa tidak ada yang akan masuk surga kecuali bangsa

${ }^{60}$ Āli ‘Imrān: 67.

61 Yūnus: 84.

62 Āli 'Imrān: 52.

63 Muḥammad Ibrāhīm Al-Hamīd, Rasäil Fì Al-Adyān Wa Al-Farq AlMadhāhib (Zulfi, n.d.), 72-73. 
M. Kholid Muslih, Amal Fathullah Zarkasyi, Abdul Rahman, Rahmat Adi Nur Rifa Da’i

Yahudi dan meskipun mereka bermaksiat tidak akan dimasukkan ke dalam neraka, kecuali hanya beberapa saat saja. Pendapat ini berangkat dari anggapan bahwa mereka sudah dijanjikan surga dan bebas dari ancaman neraka. Kenyataannya, di dalam al-Qur'an

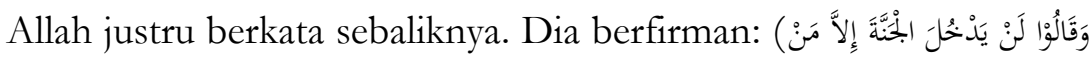

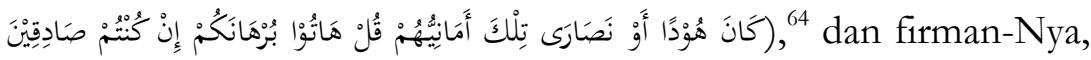

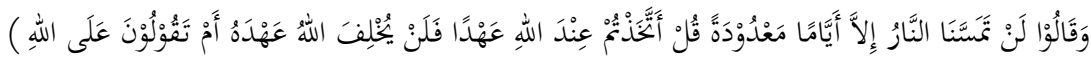

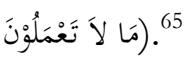

Salah satu kesalahan ideologi Zionisme lainnya adalah bahwa mereka memosisikan semua orang selain Yahudi hanyalah budak dan hewan, bukan manusia, dan anak perempuan mereka itu najis. Pandangan ini didasarkan atas pemikiran Zionisme bahwa orang non-Yahudi bukanlah keturunan Nabi Adam. Hal inilah yang kemudian membuat para Zionis menindas golongan selain mereka. Ideologi seperti ini tentunya bertentangan dengan hukum dan prinsip Islam. Islam adalah agama yang adil dan penuh kasih sayang kepada seluruh alam (rabmatan li-l 'alamin). ${ }^{66}$ Di dalam al-

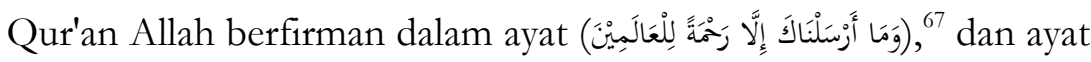

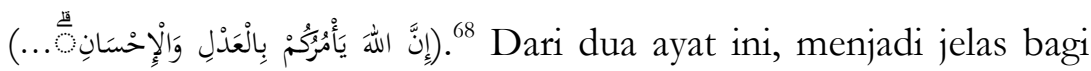
kita bahwa Islam memerintahkan kita semua untuk menunjukkan belas kasihan kepada semua orang, dan agar senantiasa berbuat adil dalam segala urusan hingga tercipta kebajikan. ${ }^{69}$ Oleh karena itu,

${ }^{64}$ Al-Baqarah: 111.

${ }^{65}$ Al-Baqarah: 80.

${ }^{66}$ Mohammad Muslih et al., "Sunan Kalijaga's Da'wah Strategy in Suluk Linglung and Its Implication to Indonesia Radicalism Movement," El Harakah 23, no. 1 (2021): https://doi.org/http://dx.doi.org/10.18860/eh.v23i1.11672.

${ }^{67}$ Al-Anbiyā: 107.

68 Al-Naḥl: 90.

69 Al-Qāḍ̂̄ Abū Muḥammad berpendapat tentang makna keadilan dan ihsan. Keadilan adalah menunaikan hal-hal yang diwajibkan serta diyakini menurut syariat, memenuhi amanah, berbuat adil, dan memberikan hak makhluk. Sedangan, ihsan adalah mengerjakan hal-hal yang disunnahkan bagi 
pemikiran Zionisme ini selain berseberangan dengan doktrin Islam juga bertentangan dengan fitrah seorang manusia untuk selalu bersikap baik dan mengasihi kepada sesamanya.

Kritik terhadap pemikiran Zionisme tentang posisi bangsa selain Yahudi juga difirmankan Allah Ta'ala dalam ayat: ( بأئَّهَا النَّاسُ إِنَّا

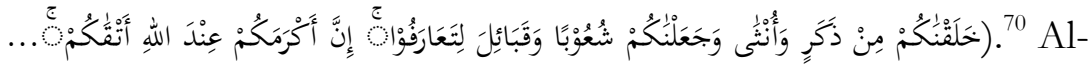
Thabari dalam kitab tafsirnya mengatakan bahwa Allah Swt., menjadikan manusia berbangsa-bangsa dan bersuku-suku dari jenis garis keturunan yang berbeda-beda agar mereka saling mengenal bukan karena untuk membedakan keunggulan dan derajat satu

hamba, karena setiap amal itu ada yang wajib dan yang sunah. Lihat: Abū Muḥammad 'Abd al-Ḥaqq Ibn 'Ațiyyah Al-Andalūsī, Al-Muharrar Al-Wajiž. Fi Tafsì Al-Kitāb Al-'Až̀z (Beirut: Dār Ibn Hazm, n.d.), 1111. Sedangkan, al-Ṭabarī mengutip pendapat Ibn Abbas Ra, yang mengatakan, "Adil yaitu bersaksi bahwa tidak ada Tuhan selain Allah dan ihsan adalah pemenuhan kewajiban." Intinya disini bahwa keadilan tiada lain adalah agama Islam itu sendiri. Lihat: Abū Ja'far Muḥammad Ibn Jarīr Al-Ṭabarī, 'Jāmi’ Al-Bayān 'an Ta'Wīl Ay Al-Qur'ān: Tafsīr Al-Ṭabarī,” Vol. 7 (Kairo: Dār al-Hadith, 2010), 247; Lihat juga: Abū alFidā Ismā̄̄l Ibn Kathīr, "Tafsīr Al-Qur'ān Al-'Aẓ̌im," Juz 7 (Riyad: Dār Ṭayyibah, 1999), 595; Abū 'Abdillah Muḥammad Abū bakr Al-Qurțūbī, "AlJāmi’ Li Aḥkām Al-Qur’ān Wa Al-Mubayyin Limā Tadlammanathu Mi AlSunnah Wa Ay Al-Furqān," Juz 12 (Beirut: Muassasah al-Risālah, 2006), 412; Abū Muḥammad al-Husain Mas'ūd Al-Baghawī, "Ma'ālim Al-Tanzīl: Tafsīr AlBaghawī," Vol. 5 (Riyad: Dār TTayyibah, n.d.), 38; Muḥammad Al-Rāzī, "AlTafsīr Al-Kabīr Wa Mafātīh Al-Ghayb,” Juz 20 (Beirut: Dār al-Fikr, 1981), 102; Abū al-Fadll Shihāb al-Dīn al-Alūsī Al-Baghdadī, "Rūḥ Al-Ma'ānī Fī Tafsīr AlQur’ān Al-'Aẓ̄im Wa Al-Sab’ Al-Mathānī,’ Juz 15 (Beirut: Dār Iḥyā al-Turāth al'Arabī, n.d.), 218; 'Abd al-Raḥmān Ibn al-Kamāl Jalāl al-Dīn Al-Suyūṭī, "Tafsīr Al-Durr Al-Manthūr F̄i Al-Tafsīr Al-Ma'thūr,” Juz 5 (Beirut: Dār al-Fikr, 2011), 160; Abū Ḥayyān Al-Andalūsī, “Tafsīr Al-Baḥr Al-Muhīṭ,” Juz 5 (Beirut: Dār alKutub al-'Ilmiyyah, 1993), 513. Di sisi lain, terdapat pendapat seorang filsuf kontemporer bernama Syed Naqib al-Attas, menurutnya keadilan adalah apa yang ada dalam jiwa manusia dari akhlak mulia yang dengannya ia memperlakukan orang lain dengan kebaikan dan bersikap lembut kepada mereka. Selain itu, ia harus adil terhadap dirinya sendiri (dengan menjalankan kewajiban-kewajiban agama dan hak-hak fisik dan spiritual). Lihat: Syed Muhammad Naquib Al-Attas, Risalah Untuk Kaum Muslimin (Kuala Lumpur: International Institute of Islamic Thought and Civilization, 2001), 37-39.

${ }^{70}$ Al-Hujūrāt: 13. 
M. Kholid Muslih, Amal Fathullah Zarkasyi, Abdul Rahman, Rahmat Adi Nur Rifa Da’i

sama lain, ${ }^{71}$ karena bagi Allah umat yang paling mulia di sisi-Nya adalah yang paling saleh dan bertakwa di antara mereka. Kesempurnaan bukan hanya ditentukan dari bentuk fisik namun paling penting adalah kesempurnaan jiwanya. Kesempurnaan jiwa menurut Ibnu Sina tergantung kepada iman seseorang yang dilandasi ilmu dan dibuktikan dengan amal. ${ }^{72}$

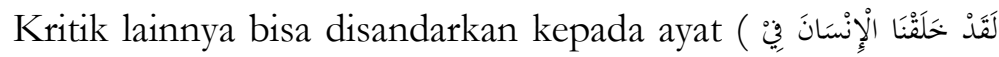
(أَحْسَنِ تَقْوِيعِ ${ }^{73}$ Ibnu Katsir mengatakan dalam kitab tafsirnya bahwa Allah menciptakan manusia dalam postur tubuh yang terbaik, tegak, dan lurus. ${ }^{74}$ Selain itu, bagi al-Baghawi kesempurnaan manusia yaitu dianugerahi akal oleh Allah Swt., sehingga dapat menentukan sesuatu dengan bijak dan benar. ${ }^{75}$ Manusia diciptakan oleh Allah sebagai khalifah, dia menempati posisi sentral di bumi dan sebagai wujud keberadaaan dan kekuasaan Allah yang mewakili asma' dan sifat-Nya. ${ }^{76}$ Dari ayat ini klaim Zionis bahwa kaum selain mereka adalah binatang dan anak-anak perempuan mereka najis telah gugur. Secara umum, semua manusia hakikatnya sama dalam bentuk dan susunan tubuhnya meskipun berbeda ras dan suku. Yang membedakan manusia hanyalah perbedaan genetik yang menjadikan bentuk wajah, warna kulit, dan postur tubuhnya sedikit berbeda.

71 Abū Ja’far Muḥammad Ibn Jarīr Al-Ṭabarī, 'Jāmi’ Al-Bayān 'an Ta’Wīl Ay Al-Qur'ān: Tafsīr Al-Ṭabarī,” Vol. 1 (Kairo: Dār al-Hadith, 2010), 297-300.

${ }^{72}$ Jarman Arroisi and Rahmat Ardi Nur Rifa Da'i, "Konsep Jiwa Perspektif Ibn Sina," ISLAMICA: Jurnal Studi Keislaman 13, no. 2 (2019): 263, https://doi.org/https://doi.org/10.15642/islamica.2019.13.2.323-345.

73 Al-Tin: 4.

74 Abū al-Fidā Ismā’îl Ibn Kathīr, “Tafsīr Al-Qur’ān Al-'Aẓīm,” Juz 8 (Riyad: Dār Țayyibah, 1999), 435.

75 Abū Muḥammad al-Ḥusain Mas'ūd Al-Baghawī, "Ma'ālim Al-Tanzîl: Tafsīr Al-Baghawì,” Vol. 8 (Riyad: Dār Ṭayyibah, n.d.), 472.

76 M. Kholid Muslih, "Konsep Tuhan," in Worldview Islam: Pembahasan Konsep-Konsep Penting Dalam Islam, ed. M. Kholid Muslih et al. (Ponorogo: Direktorat Islamisasi Ilmu, 2019), 43; Hammis Syafaq, "Relasi Pengetahuan Islam Eksoteris Dan Esoteris," Teosofi: Jurnal Tasawuf Dan Pemikiran Islam 2, no. 2 (2012): 339. 
Dalam Talmud juga tertulis bahwa Nabi Adam pernah menggauli binatang ketika berada di surga. Keyakinan ini adalah delusi. Sebagai seorang muslim kita percaya bahwa nabi-nabi dan rasul-rasul itu terjaga (ma'shum) dari maksiat dan dosa besar yang paling tercela, ${ }^{77}$ dan bukan dosa kecil $^{78}$ (terkecuali Nabi Muhammad saw.). Pendapat ini dilontarkan oleh sebagian besar ulama dan semua sekte, dan itu juga ucapan sebagian besar ahli tafsir, ahli hadis, dan ahli fikih, bahkan tidak pernah didapati pendapat ulama' salaf, imam, sahabat, tabi'in. dan tabi'ut tabi'in kecuali yang setuju dengan pendapat ini. ${ }^{79}$ Selain itu, klaim Zionisme ini bertentangan dengan pernyataan mereka sebelumnya bahwa orang selain mereka adalah binatang dan anak perempuannya najis. Ada dua alasan untuk itu, pertama, mereka mengatakan jika bangsa selain mereka adalah binatang, dan anak perempuannya itu najis, dikarenakan bukan dari keturunan Adam. Ini berarti, Zionis menganggap bahwa Nabi Adam itu nabi yang suci dari hal-hal buruk. Tetapi kemudian mereka berpendapat bahwa Nabi Adam telah bersetubuh dengan binatang, artinya Nabi Adam telah berdosa setelah berzina dengan binatang. Dari sini menjadi jelas bagi kita adanya kontradiksi antara dua keyakinan di dalam Talmud. Sehingga, runtuhlah keyakinan mereka itu karena kitab yang isinya saling bertentangan itu dianggap tidak valid dan tidak layak dijadikan pedoman, meskipun Zionis mengatakan bahwa Talmud adalah kitab suci yang dinukil dari Taurat, seperti yang disebutkan dalam penelitian sebelumnya.

Dalam Talmud juga tertulis bahwa seorang rabbi (pendeta) telah mengalahkan tuhan mereka (Yahweh) dalam berdebat sehingga Yahweh mengakui keunggulan ilmu dan kecerdasan si

77 Al-Qaḍī Abū al-Fadlal 'Iyādl Ibn Musā Al-Yaḥṣabī, Al-Shifā Bi Ta'rūf Huqūq Al-Muștafāa (Beirut: Muassasah al-Risālah, 2006), 227.

78 Aḥmad Ibn 'Abd al-Hạīm Ibn Taimiyyah, "Majmū' Fatāwā Shaykh AlIslām Aḥmad Ibn Taimiyyah,” Juz 4 (Arab Saudi: Majmū’ al-Malik Fahd li Ṭibā’ah al-Muṣḥaf al-Sharîf, 2004), 319.

79 Taimiyyah, 319.

TAJDID Vol. 20, No. 2, Juli - Desember 2021 | 291 
M. Kholid Muslih, Amal Fathullah Zarkasyi, Abdul Rahman, Rahmat Adi Nur Rifa Da’i

rabbi. Frasa ini menunjukkan kerusakan konsep Tuhan dalam Talmud. Seharusnya, Tuhan itu bersifat al-'Alim (Maha Mengetahui), ilmu-Nya tidak terbatas yang meliputi seluruh langit dan bumi. Sebagaimana dinyatakan dalam al-Qur'an: (هُوَ الَّذِيْ خَكَقَ لَكْمُ

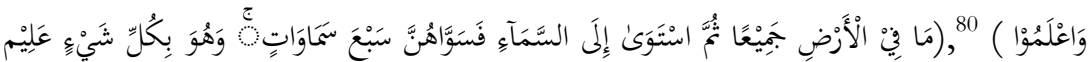

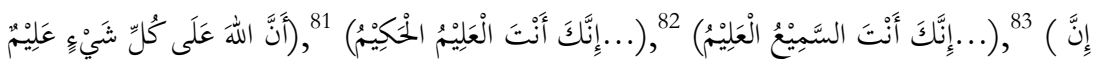

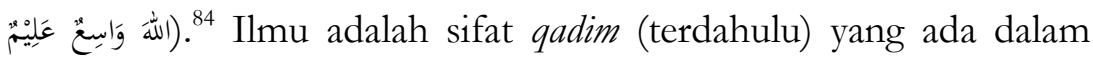
Dzat Allah, dengannya akan tersingkap dan diketahui segala sesuatu tanpa ada yang bisa disembunyikan. Sifat al-ílm Allah sudah ada sejak zaman azali secara sempurna. Ilmu Allah bukan berdasarkan dugaan maupun keraguan, karena dugaan dan keraguan tidak mungkin bagi-Nya. ${ }^{85}$ Dan ilmu adalah salah satu sifat kesempurnaan Tuhan. Maka yang tidak memilikinya tidak memiliki sifat kesempurnaan dan akan dinisbatkan sifat kekurangan dan kelemahan baginya, dan yang tidak sempurna tidak dapat dikatakan Tuhan. ${ }^{86}$ Tuhan dalam Islam tidak dapat disamakan dengan segala sesuatu apapun, Dia bersifat Esa dan sempurna dalam segala hal, dan kesempurnaan-Nya tidak dapat digambarkan dengan suatu uraian yang bisa dinalar oleh akal manusia. ${ }^{87}$ Dari sini, konsep tuhan (Yahweh) dalam Talmud sudah menunjukkan kerusakannya karena mereka mengisahkan Yahweh telah dikalahkan keilmuannya oleh seorang manusia.

80 Al-Baqarah: 29.

81 Al-Baqarah: 231.

82 Al-Baqarah: 32.

83 Al-Baqarah 128.

${ }^{84}$ Al-Baqarah: 115.

${ }^{85}$ Muḥammad Al-Fudlālī, Kifāyah Al-'Awwām (Surabaya: Dār al-'Ilm, n.d.), $50-51$.

86 Ibn 'Athā'illāh Al-Sakandārī, Miftāh Al-Falāh Wa Miṣbāh Al-Arwāh Fì Żikrillāh Al-Karim Al-Fattāh (Beirut: Dār al-Kutub al-'Ilmiyyah, n.d.), 58.

${ }^{87}$ Shofiyullah Muzammil, "Mempertimbangkan Kembali Konsep Tentang Tuhan, Manusia, Dan Aql Dalam Filsafat AL-Kindi Dan Seyyed Hossein Nasr," Tajdid 17, no. 1 (2018): 14-15. 
Zionis mengklaim diri mereka sebagai pengikut Nabi Musa a.s., dan kitab pedoman mereka (Talmud) itu merupakan nukilan dari Taurat. Taurat yang asli adalah kitab yang agung, ia adalah cahaya yang memberikan petunjuk seperti yang Allah firmankan:

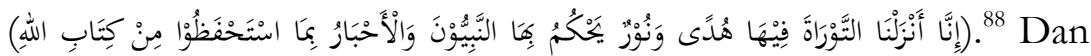

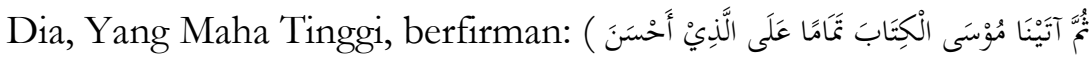

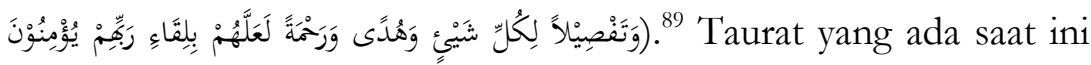
mencakup lima kitab: Kejadian, ${ }^{90}$ Keluaran, ${ }^{91}$ Imamat, ${ }^{92}$ Bilangan, ${ }^{93}$ dan Ulangan. ${ }^{94}$ Taurat ini telah diubah dan diselewengkan karena sebelum tahun 945 SM sampai kehancuran yang ketujuh terjadi pada tahun $613 \mathrm{M}$, yang menunjukkan hilangnya dan terputusnya sanad. Di dalamnya terkandung kepercayaan yang salah dan adanya pertentangan yang terjadi antara Taurat sekarang dan fakta-fakta ilmu pengetahuan modern membuktikan kesalahan ilmiah di dalamnya. Di antara buku-buku yang mengkajinya adalah buku yang berjudul "The Origin of Man" dan "The Torah, the Bible, and the Qur'an" yang ditulis oleh seorang ilmuwan Prancis bernama Maurice Bucaille, di mana ia membuktikan adanya kesalahan ilmiah. dalam Taurat dan Injil, dan pada saat yang sama membuktikan bahwa al-Qur'an tidak bertentangan dengan ilmu pengetahuan modern berikut juga fakta-faktanya. Bahkan dia mencatat bukti-bukti keunggulan al-Qur'an yang mendahului ilmu

88 Al-Māidah: 44.

89 Al-An'ām: 154.

90 Buku ini berbicara tentang penciptaan dunia, penampakan manusia, banjir Nabi Nuh, kelahiran Nabi Ibrahim hingga wafatnya Nabi Yusuf As.

${ }^{91}$ Dia berbicara tentang kehidupan Bani Israel di Mesir, dari zaman Nabi Ya'qub hingga eksodus mereka ke tanah Kanaan Bersama Nabi Musa dan Yosua bin Nun As.

92 Berkaitan dengan Lewi bin Nabi Ya'qub, dan dalam buku ini ada pembicaraan tentang kesucian, kenajisan, persembahan korban, nazar, dan pemuliaan Nabi Harun dan putra-putranya.

${ }^{3}$ Dia menghitung suku Bani Israil sejak Nabi Ya'qub, dan kaum mereka, dan ternak mereka.

94 Ini berisi ketentuan, ibadah, politik, masyarakat, ekonomi dan tiga pidato Nabi Musa As.

TAJDID vol. 20, No. 2, Juli - Desember 2021 | 293 
M. Kholid Muslih, Amal Fathullah Zarkasyi, Abdul Rahman, Rahmat Adi Nur Rifa Da’i

pengetahuan selama seribu empat ratus tahun. Taurat yang ada saat ini telah diselewengkan, ia bukan Taurat yang diwahyukan kepada Nabi Musa a.s., ${ }^{95}$ dan oleh karena itu kita tidak dapat mengambil Taurat yang ada sekarang sebagai dasar pedoman.

Selanjutnya, ideologi yang digunakan Zionis cenderung mengarah kepada filosofi materialisme. Filosofi materialisme adalah pemahaman dalam realitas yang menolak dasar gaib dan hasil spiritualitas dalam memahami dunia ${ }^{96}$ dan hanya percaya kepada unsur material (terlihat oleh mata). ${ }^{97}$ Dengan kata lain, pemahaman ini menolak adanya konsep Tuhan. ${ }^{98}$ Mereka sengaja menghilangkan gagasan tentang Tuhan dari pikiran orang-orang dan menggantinya dengan hukum fisika matematika. Filosofi materialisme di dalam Islam tertolak. Sebagaimana gagasan Ibnu Rushd tentang hakikat Islam adalah agama yang meyakini adanya Tuhan dalam setiap elemen dunia dan kehidupan. ${ }^{99}$ Alam semesta dan manusia diciptakan untuk menunjukkan nama-nama dan sifatsifat-Nya. ${ }^{100}$ Sa’id al-Nursi menegaskan lagi pandangan Ibnu Rushd, menurutnya setiap fenomena dunia memiliki makna yang esensial dan yang gaib, yaitu Tuhan, ${ }^{101}$ Oleh karena itu, Tuhan, alam, dan manusia tidak dapat dipisahkan satu sama lain, ketiganya

${ }^{95}$ Maurice Bucaille, Al-Taurah Wa Al-Injül, Wa Al-Qur'ān Wa Al-Tlm, ed. Ḥasan Khālid (Beirut: Al-Maktab al-Islāmī, 1990), 251.

${ }^{96}$ Al-Basit, "Said Nursi's Approach to The Stories of The Qur'an," in The Fourth International Symposium On Bediuzzaman Sa'id Nursi: A Contemporary Approach Toward Understanding The Qur'an: The Example of Risale-I Nur (Istanbul, 1998), 682-84.

${ }^{97}$ Jostein Gaarder, Dunia Shopie (Bandung: Mizan, 1997), 60.

98 Fuad Mahbub Siraj and Muhammad Husni, "Kenabian Dalam Pandangan Badiuzzaman Said Nursi: Sebuah Respon Terhadap Gagasan Materialisme Barat," Jurnal Khazanah 18, no. 1 (2020): 94.

${ }^{99}$ Ibnu Rushd, Al-Kashf 'an Manabij Al-Adillah Fi 'Aqaidi Al-Millah, ed. Muhammad Abid Al-Jabiri (Beirut: Markaz Dirasat al-Wahdat al-'Arabiyah, 1998), 45.

100 Hamid Fahmy Zarkasyi et al., "Ibn Rushd's Intellectual Strategies on Islamic Theology," Jurnal Ilmiah ISL AM FUTURA 20, no. 1 (2020): 24.

101 Siraj and Husni, "Kenabian Dalam Pandangan Badiuzzaman Said Nursi: Sebuah Respon Terhadap Gagasan Materialisme Barat,” 96. 
saling terikat karena dari esensi yang sama yaitu Tuhan. ${ }^{102}$ Konsekuensinya di sini adalah cara pandang (worldview) taubidi terhadap dunia. ${ }^{103}$ Berbeda halnya dengan ideologi Zionisme yang didasarkan pada filosofi materialisme yang menjadikan mereka terlepas dari moral "loss of adab" dalam segala pemikiran dan keyakinannya.

Di sisi lain, dari Protocols of Zion kita dapat memahami bahwa Zionis sedang berjalan dan belajar untuk mewujudkan ambisi dan impian masa depan mereka, dengan mendirikan Negara Besar Israel yang menguasai dunia, mereka tidak puas dengan Palestina saja. Mereka berjuang keras untuk melepaskan pengepungan bangsa lain terhadap mereka, mereka tahu cara untuk menghilangkan penghalang antara mereka dan kaum Muslimin dengan mengatasnamakan perdamaian di waktu-waktu tertentu dan atas nama normalisasi di waktu-waktu yang lain. Hal seperti itu terjadi dan ada normalisasi antara mereka dan beberapa negara Arab, sehingga mereka menemukan peluang untuk melakukan kerusakan dan penghancuran, juga menyebarkan kemaksiatan dan amoralitas, seperti yang terjadi di Mesir dan lainnya. Mereka tidak akan puas sampai kita menjadi pengikut mereka dan terlibat dengan mereka dalam hal apapun yang mereka inginkan. Dan

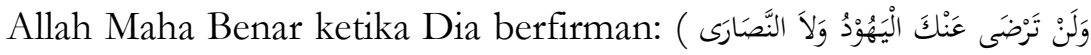

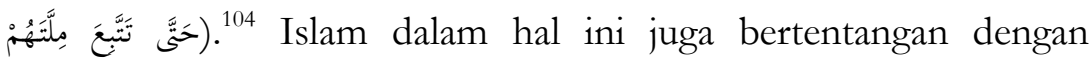
Zionis, karena dalam Islam nilai kebenaran dan keadilan sangat dijunjung tinggi dalam hal apapun lebih-lebih urusan bernegara. ${ }^{105}$ Manusia dituntut untuk menjunjung tinggi adab dan kerukunan

102 Suhermanto Ja'far, "Konsep Being Perspektif Filsafat Islam," ISLAMICA: Jurnal Studi Keislaman 11, no. 2 (2017): 523-24.

103 Al-Sakandārī, Miftāh Al-Falāh Wa Miṣbāh Al-Arwāh Fì Żikrillāh AlKarim Al-Fattäh, 40.

104 Al-Baqarah: 12.

105 Ahmad Nur Fuad, "Nizam Al-Mulk Dan Kontribusinya Terhadap Pemikiran Politik Islam," ISLAMICA: Jurnal Studi Keislaman 13, no. 1 (2018): 152.

TAJDID vol. 20, No. 2, Juli - Desember 2021 | 295 
M. Kholid Muslih, Amal Fathullah Zarkasyi, Abdul Rahman, Rahmat Adi Nur Rifa Da’i

didalamnya. ${ }^{106}$ Islam adalah agama yang memberi keteduhan kepada seluruh manusia dalam berbagai aspek kehidupan, ia menganjurkan manusia untuk saling merajut kasih dan kebersamaan dan membenci permusuhan. ${ }^{107}$

\section{Penutup}

Zionisme adalah sebuah sekte politik rasis, sebuah kesesatan yang menyimpang dari segala sesuatu yang telah diatur dalam Kitab Suci. Mereka akan melakukan segala cara untuk keberhasilan citacita mereka yang rusak. Mereka berperang dengan orang yang menghalanginya seperti yang terjadi pada orang-orang Arab, khususnya di Palestina. Zionisme adalah bentuk Yudaisme pada zaman ini. Mereka selalu membuat intrik dan kerusakan di dunia sebagaimana faktanya sekarang. Mereka berusaha mendirikan Negara Yahudi Israel di tempat yang tidak berperikemanusiaan.

Kita mengetahui bahwa mereka berpegang pada apa yang ada dalam Protocols of Zion dan Talmud, yaitu kitab Taurat yang telah diubah dan tercampuri perkataan Ahli Kitab Yahudi. Banyak keburukan, kejahatan, dan penyimpangan didalamnya, baik dalam kepercayaan maupun pemikiran. Setelah peneliti memaparkan dan menganalisis keyakinan dan pemikiran-pemikiran tersebut, peneliti kemudian mengkritiknya dari sisi doktrin Islam dan teorinya dari al-Qur'an, sunnah, dan perkataan para ulama. Peneliti menemukan kontradiksi dari beberapa kepercayaan dan pemikiran mereka sampai mencapai kesimpulan bahwa banyak kepercayaan dan pemikiran dalam Talmud yang keliru dan tidak valid. Kita sebagai umat Islam dengan keyakinan terhadap al-Qur'an harus dapat menghindari kesalahan yang ada pada ideologi Zionisme. Selain itu,

106 Masdar Hilmy, “MUSLIMS' APPROACHES TO DEMOCRACY: Islam and Democracy in Contemporary Indonesia," JOURNAL OF INDONESLAN ISLAM 1, no. 1 (2007): 57.

107 Ali Nurdin and Maulidatus Syahrotin Naqqiyah, "Model Moderasi Beragama Berbasis Pesantren Salaf," ISLAMICA: Jurnal Studi Keislaman 14, no. 1 (2019): 82-83; Syamsul Arifin et al., "Interseksi Hak Asasi Manusia Dan Shari'ah Di Indonesia," ISLAMICA: Jurnal Studi Keislaman 12, no. 2 (2018): 283. 
kecenderungan rasisme tersebut tidak sesuai dengan sisi kemanusian. Perlu dilakukan upaya damai antara pihak Israel dan Palestina untuk mengakhiri peperangan antara kedua belah pihak. Demi menjunjung tinggi nilai kemanusia dan Islam yang rabmatan lil 'alamin.

\section{Daftar Pustaka}

'Arābī, Rajā 'Abd al-Hamīd. Safar Al-Tārìkh Al-Yabūdì. Suriah: AlAwāil li al-Nashr wa al-Tawzì’, 2006.

Al-'Aliyy, Muḥammad Mehna. "Sira'unā Ma'a Al-Yahūdiyyah Baina Al-Ṣulḥ Al-Mustaḥil Wa Muwājahah Al-Ḥatmiyyah," Vol. 1. Riyad: Dār 'Āmiyyah li al-Nașr wa al-Tauzī', 1993.

Al-'Ifār, 'Abbās Maḥmūd. Al-Khaṭr Al-Yabūdì: Burtūkūlät Hukamā Șubyūn. Beirut: Dār al-Kitāb al-'Arabī, 1961.

Al-Andalūsī, Abū Ḥayyān. "Tafsīr Al-Baḥr Al-Muhịịt," Juz 5. Beirut: Dār al-Kutub al-'Ilmiyyah, 1993.

Al-Andalūsī, Abū Muḥammad 'Abd al-Ḥaqq Ibn 'Ațiyyah. AlMubarrar Al-Wajī̌ Fì Tafsìr Al-Kitāb Al-'Až̀̃. Beirut: Dār Ibn Hazm, n.d.

Al-Attas, Syed Muhammad Naquib. Risalab Untuk Kaum Muslimin. Kuala Lumpur: International Institute of Islamic Thought and Civilization, 2001.

Al-Baghawī, Abū Muḥammad al-Ḥusain Mas'ūd. "Ma'ālim AlTanzīl: Tafsīr Al-Baghawī,” Vol. 8. Riyad: Dār Ṭayyibah, n.d. . "Ma'ālim Al-Tanzīl: Tafsīr Al-Baghawī," Vol. 5. Riyad: Dār Ṭayyibah, n.d.

Al-Baghdadī, Abū al-Fadll Shihāb al-Dīn al-Alūsī. "Rūḥ Al-Ma'ānī F̄̄ Tafsīr Al-Qur'ān Al-'Aẓīm Wa Al-Sab’ Al-Mathānī,” Juz 15. Beirut: Dār Ihỵā al-Turāth al-'Arabī, n.d.

Al-Basit. "Said Nursi's Approach to The Stories of The Qur'an." In The Fourth International Symposium On Bediurzaman Sa'id Nursi: A Contemporary Approach Toward Understanding The Qur'an: The Example of Risale-I Nur. Istanbul, 1998.

TAJDID Vol. 20, No. 2, Juli - Desember 2021 | 297 
M. Kholid Muslih, Amal Fathullah Zarkasyi, Abdul Rahman, Rahmat Adi Nur Rifa Da’i

Al-Fudlālī, Muḥammad. Kifāyah Al-'Awwām. Surabaya: Dār al-'Ilm, n.d.

Al-Ghādirī, Nihād. Al-Tärìkh Al-Sirrì Li Al-'Alāqāt Al-Shuyü'Iyyah Al-Subyunniyyah. Beirut: Manshūrāt Dār al-Kitāb al-'Arabī, 1969.

Al-Hamīd, Muḥammad Ibrāhīm. Rasāil Fì Al-Adyān Wa Al-Farq Al-Madhäbib. Zulfi, n.d.

Al-Hasan, Muhammad. Al-Madhäbib Wa Al-Afkār Al-Mu'āṣirah Fì Al-Tașawnur Al-Islāmì. Țanțā: Dār al-Bashīr li al-Thaqāfah wa al-'Ulūm al-Islāmī, 1999.

Al-Maysirī, 'Abd al-Wahhāb Muḥammad. Al-Idiyūiūizyyah AlȘubyūniyyah. Beirut: 'Ālam al-Ma'rifah, 1982.

Al-Qurțūbī, Abū 'Abdillah Muḥammad Abū bakr. “Al-Jāmi’ Li Aḥkām Al-Qur’ān Wa Al-Mubayyin Limā Tadlammanathu Mi Al-Sunnah Wa Ay Al-Furqān,” Juz 12. Beirut: Muassasah al-Risālah, 2006.

Al-Rāzī, Muḥammad. "Al-Tafsīr Al-Kabīr Wa Mafātīh Al-Ghayb,” Juz 20. Beirut: Dār al-Fikr, 1981.

Al-Sakandārī, Ibn 'Athā'illāh. Miftāh Al-Falāh Wa Miṣbāḥ AlArwāh Fì Żikrillāh Al-Karim Al-Fattäh. Beirut: Dār al-Kutub al-'Ilmiyyah, n.d.

Al-Saqāa, 'Alwī Ibn 'Abd al-Qādir. "Mawsū'ah Al-Milal Wa AlAdyān,” Juz 1., n.d.

Al-Shaqifī, Nadā. Al-Holocaust: Haqiqaatibā Wa Al-Ishtighāl AlSubyūñ Lahā. Beirut, 2011.

Al-Suyūṭī, 'Abd al-Raḥmān Ibn al-Kamāl Jalāl al-Dīn. "Tafsīr AlDurr Al-Manthūr Fī Al-Tafsīr Al-Ma'thūr,” Juz 5. Beirut: Dār al-Fikr, 2011.

Al-Ṭabarī, Abū Ja’far Muḥammad Ibn Jarīr. "Jāmi’ Al-Bayān 'an Ta'Wīi Ay Al-Qur'ān: Tafsīr Al-Ṭabarī,” Vol. 7. Kairo: Dār al-Hadith, 2010.

. 'Jāmi' Al-Bayān 'an Ta’Wīl Ay Al-Qur'ān: Tafsīr AlṬabarī,” Vol. 1. Kairo: Dār al-Hadith, 2010.

298 | TAJDID vol. 20, No. 2, Juli - Desember 2021 
Al-Yaḥ̣abīin, Al-Qaḍī Abū al-Fadlal 'Iyādl Ibn Musā. Al-Shifā Bi Ta'rîf Huqūq Al-Mușțafā. Beirut: Muassasah al-Risālah, 2006.

Al-Zeibik, Ali Muhammad Jareshah, and Muhammad Sharif. Asalib Al-Ghazw Al-Fikriy Li Al-'Alam Al-Islamiy. Kairo: Dar alI'tisham, 1975.

Al-Zubaiq, 'Al̄̄ Muḥammad Grishāh, and Muḥammad Sharīf. AlAsālīb Al-Ghaẓw Al-Fikrì Li Al-'Ālam Al-Islàmī. Kairo: Dār al-I'tiṣām, 1979.

Ali Nurdin, and Maulidatus Syahrotin Naqqiyah. "Model Moderasi Beragama Berbasis Pesantren Salaf." ISLAMICA: Jurnal Studi Keislaman 14, no. 1 (2019).

Arifin, Syamsul, Nafik Muthohirin, Tongat, and Wahyudi. "Interseksi Hak Asasi Manusia Dan Shari'ah Di Indonesia." ISLAMICA: Jurnal Studi Keislaman 12, no. 2 (2018).

Arroisi, Jarman, and Rahmat Ardi Nur Rifa Da'i. "Konsep Jiwa Perspektif Ibn Sina." ISLAMICA: Jurnal Studi Keislaman 13, no. 2 (2019). https://doi.org/https://doi.org/10.15642/islamica.2019.13. 2.323-345.

Badarussyamsi, M. Ridwan, and Nur Aiman. "Amar Ma'ruf Nahi Munkar: Sebuah Kajian Ontologis.” Tajdid 19, no. 2 (2020).

Baharun, Muhammad. Isu Zionisme Internasional. Yokyakarta: Pustaka Pelajar, 1979.

Bakhrabeh, Muhamammad. Al-Subyūniyyah Bi İjār. Așl Nash'ah AlMukhatțațāt Al-Subyüniyyah Al-'Alamiyyah Dhät Al-Naz'Ah Al-Unșuriyyah, 2001.

Bakr, 'Ala. Mazahib Fikriyah Fi Al Mizan. Kairo: Dar al-'Aqidah, 2002.

Bakr, Abū. Madbāhib Fikriyyah Fì Al-Mì̃àn. Kairo: Dār al-'Aqiīdah, 2002.

Bucaille, Maurice. Al-Taurah Wa Al-Injīl, Wa Al-Qur'àn Wa Al-Tlm. Edited by Hasan Khālid. Beirut: Al-Maktab al-Islāmī, 1990.

Daldjoeni, N. Ras-Ras Umat Manusia: Biogeografis, Kulturbistoric, Sosiopolitis. Bandung: Citra Aditya Bakti, 1991.

TAJDID vol. 20, No. 2, Juli - Desember 2021 | 299 
M. Kholid Muslih, Amal Fathullah Zarkasyi, Abdul Rahman, Rahmat Adi Nur Rifa Da’i

Epafras, Leonard C. "Memahami Ingatan Kuktural Yahudi Dalam Konflik Israel-Palestina." Jurnal Kawistara 3, no. 2 (2013).

Fuad, Ahmad Nur. "Nizam Al-Mulk Dan Kontribusinya Terhadap Pemikiran Politik Islam." ISLAMICA: Jurnal Studi Keislaman 13, no. 1 (2018).

Fuhaidah, Ulya. "Analisis Peluang Kedaulatan Negara Palestina." Jurnal Review Politik. 2, no. 1 (2012).

Gaarder, Jostein. Dunia Shopie. Bandung: Mizan, 1997.

Grosfoguel, Ramon. "What Is Racism?" Journal of World-System Research 22, no. 1 (2016).

Hammis Syafaq. "Relasi Pengetahuan Islam Eksoteris Dan Esoteris." Teosofi: Jurnal Tasawuf Dan Pemikiran Islam 2, no. 2 (2012).

Hidayah, Zulzani. Ensiklopedia Suku Bangsa Di Indinoseia. Jakarta: LP3ES, 1996.

Hilmy, Masdar. "MUSLIMS' APPROACHES TO DEMOCRACY: Islam and Democracy in Contemporary Indonesia." JOURNAL OF INDONESLAN ISLAM 1, no. 1 (2007).

Ja'far, Suhermanto. "Konsep Being Perspektif Filsafat Islam." ISLAMICA: Jurnal Studi Keislaman 11, no. 2 (2017).

Jābir, Abū, and Ibrāhīm. Qadliyyah Al-Quds Wa Mustaqbalubā Fì AlQarn Al-Hādì Wa Al-Ishrìn. Oman: Markaz Dirāsāt al-Shirq al-Awsat, 2002.

Julkarnain, Muhammad. "Resolusi Jihad Muslim Nusantara Abad XVIII: Interpretasi Jihad 'Abd Al-Samad Al-Falimbani." Tajdid 15, no. 1 (2016).

Kathīr, Abū al-Fidā Ismā’īl Ibn. "Tafsīr Al-Qur'ān Al-'Aẓ̄im,” Juz 8. Riyad: Dār Ṭayyibah, 1999.

—. "Tafsīr Al-Qur’ān Al-‘Ạīm,” Juz 7. Riyad: Dār Ṭayyibah, 1999.

Khumairoh, Mahlil Idatul, and Abdul Fadhil. "Gerakan Intifadhah Dan Kemunculan Hamas (1987-1993).” PERIODE: Jurnal

300 | TAJDID vol. 20, No. 2, Juli - Desember 2021 
Sejarah Dan Pendidikan Sejarah 1, no. 1 (2019).

Liliwesi, Alo. Prasangka Dan Konflik: Komunikasi Lintas Budaya Multikultur. Yogyakarta: LKiS, 2005.

Maḥmūd, 'Alwi 'Abd al-Halīm. Al-Ghažn Al-Fikerì Wa Al-Tayyārāt Al-Ma'āiiyyah Li Al-Islām. Riyadl: Idārah al-Thaqāfah wa alNashr bi al-Jāmi’ah, n.d.

Māni’ Ḥammād al-Jawhānī. "Al-Mawsū’ah Al-Muyassarah F̄̄ AlAdyān Wa Al-Madhāhib Wa Al-Ahzāb Al-Mu'āṣirah,” Juz 1. Riyad: Dār al-Nadwah al-'Ālamiyyah li al-Ṭibā’ah wa alNashr wa al-Tawzī', n.d.

Maulani, Z.A. Zionisme: Gerakan Menaklukkan Dunia. Jakarta: Daseta, 2002.

MN, Aguk Irawan. Rahasia Dendam Israel. Jakarta: Kinza Books, 2009.

Moh. Rosyid. "Dinamika Perjuangan Muslim Di Palestina." Fikrah: Jurnal Ilmu Aqidah Dan Studi Keagamaan 3, no. 2 (2015).

Mubarak. "Yahudi Dan Islam Dalam Lintas Sejarah: Studi Perspektif Islam Terhadap Yahudi." Jurnal Al-Adyan 6, no. 2 (2019).

Muchsin, A. Misri. "PALESTINA DAN ISRAEL: Sejarah, Konflik Dan Masa Depan.” Jurnal Miqot 39, no. 2 (2015).

Musaph-Andriesse, R.C. From Torah to Kabbalab: A Basic Introduction to the Writings of Judaism. Britania Raya: Oxford University Press, 1982.

Muslih, M. Kholid. "Konsep Tuhan." In Worldview Islam: Pembahasan Konsep-Konsep Penting Dalam Islam, edited by M. Kholid Muslih, Anto Ismunanto, Nofriyanto, Fuad Muhammad Zein, M. Shohibul Mujtaba, Imroatul Istiqomah, Abdul Wahid, M Faqih Nidzom, and Abdul Hamid Saragih. Ponorogo: Direktorat Islamisasi Ilmu, 2019.

Muslih, Mohammad, Abdul Rohman, Ahmad, and Ahmad Saifullah. "Sunan Kalijaga's Da'wah Strategy in Suluk Linglung and Its Implication to Indonesia Radicalism Movement." El Harakah 23, no. 1 (2021). 
M. Kholid Muslih, Amal Fathullah Zarkasyi, Abdul Rahman, Rahmat Adi Nur Rifa Da’i

https://doi.org/http://dx.doi.org/10.18860/eh.v23i1.11672

Muzammil, Shofiyullah. "Mempertimbangkan Kembali Konsep Tentang Tuhan, Manusia, Dan Aql Dalam Filsafat AL-Kindi Dan Seyyed Hossein Nasr.” Tajdid 17, no. 1 (2018).

Pratama, Daniel Surya Andi. "Representasi Rasisme Dalam Film Cadillac Records.” Jurnal E-Komunikasi 4, no. 1 (2016).

Rahman, Tasnim Abdul, Zuriati Mohd Rashid, Wan Sabri Wan Yusof, and Ahmad Nabil Amir. "Konflik Islam Dan Israel Di Palestina: Tentangan, Isu, Dan Penyelesaiannya Dalam Karya AL-Faruqi." UMRAN: International Journal of Islamic and Civilizational Studies 2, no. 2 (2015).

Roma Ulinnuha. "Yahudi Dalam Sudut Pandang Filosofis Studi Agama: Kontra Zionisme Dan Kontribusi Kelompok Naturei Karta Pada Klausul Perdamaian.” Jurnal Religi 9, no. 1 (2015).

Rozali, Ermy Azziaty, and Azmul Fahimi Kamaruzaman. "First World War, Balfour Declaration and Their Impacts on Palestine: Perang Dunia Pertama, Deklarasi Balfour Dan Kesannya Terhadap Palestina." International Journal of West Asian Studies 3, no. 2 (2011). https://doi.org/DOI: 10.5895/ijwas.2011.08.

Rushd, Ibnu. Al-Kashf 'an Manahij Al-Adillah Fi 'Aqaidi Al-Millah. Edited by Muhammad Abid Al-Jabiri. Beirut: Markaz Dirasat al-Wahdat al-'Arabiyah, 1998.

Salaby, Ahmad. Agama Yahudi. Jakarta: Bumi Aksara, 1996.

Satrianingsih, Andi, and Zaenal Abidin. "Sejarah Zionisme Dan Berdirinya Negara Israel." Jurnal Adabiyah 16, no. 3 (2016).

Setiawan, Boenjamin, Eduardus Nugroho, Hadyana Pudjaatmaka, Bambang Harsrinuksmo, Dicky Soetadi, and Ansis Kleden. Ensiklopedia Nasional Indonesia. Jakarta: PT. Cipta Adi Pustaka, 1990.

Shulbī, Aḥmad. Muqāranah Al-Adyān Al-Awwal: Al-Yabüdiyyah. Juz 5. Kairo: Maktabah al-Nadwah al-Maysaroh, 1978. 
Sinokrot, Dāud 'Abd al-'Afw. Al-Yabūd Fì Al-Waṭn Al-'Arabì. Oman: Dār al-Furqān, 1983.

Siraj, Fuad Mahbub, and Muhammad Husni. "Kenabian Dalam Pandangan Badiuzzaman Said Nursi: Sebuah Respon Terhadap Gagasan Materialisme Barat.” Jurnal Khazanah 18, no. 1 (2020).

Sochamawardiah, Hesti Armiwulan. Deskriminasi Rasial Dalam Hukum Ham: Studi Tentang Deskriminasi Terbadap Etnis Tionghia. Yogyakarta: Genta Publising, 2013.

Soekamto, Soerjono. Kamus Sosiologi. Jakarta: Raja Grafindo Persada, 1993.

Taimiyyah, Aḥmad Ibn 'Abd al-Ḥalīm Ibn. "Majmū' Fatāwā Shaykh Al-Islām Aḥmad Ibn Taimiyyah,” Juz 4. Arab Saudi: Majmū’ al-Malik Fahd li Ṭibā’ah al-Muṣḥaf al-Sharīf, 2004.

Usmani, Ahmad Rofi'. Ensiklopedia Tokoh Muslim. Bandung: PT. Mizan Pustaka, 2015.

Yusuf, Nur Fadilah, and Retno Winarni. "Strategi Zionis Politik Dalam Merebut Palestina Dari Kerajaan Utsmani Tahun 1896-1948." Historia 3, no. 1 (2020).

Zarkasyi, Hamid Fahmy, Amal Fathullah Zarkasyi, Tonny Ilham Prayogo, and Rahmat Ardi Nur Rifa Da'i. "Ibn Rushd's Intellectual Strategies on Islamic Theology." Jurnal Ilmiah ISLAM FUTURA 20, no. 1 (2020).

TAJDID vol. 20, No. 2, Juli - Desember 2021 | 303 